\title{
Residential Satisfaction of the Elderly in Cooperatively Owned Housing and Rental Housing
}

\author{
Hyunjeong Lee \\ Department of Housing and Interior Design at Kyung Hee University, Seoul, Korea
}

\begin{abstract}
Aging is accompanied with numerous transitions in life, and residential environment becomes a pivotal part of the elderly's lives. Physically supportive housing linked with services emerges in midst of the reality that retrofitting housing with special features has been seriously underfunded. The purpose of this study was to examine the residential satisfaction of the elderly in two types of independent living arrangements specially designed for the elderly. The indices of residential supportiveness were developed, and the questionnaire survey was adopted for data collection. Two hundred eighty residents living in two different kinds of senior housing participated in the survey, and all the collected responses were used for data analysis. The finding showed that almost all of the elderly positively assessed their senior living. That is, the statistical analysis illustrated that satisfaction indices of senior living significantly and positively contributed the satisfaction with overall residential environment. Satisfaction with physical environment was the only strong predictor in explaining current residential satisfaction of the elderly in senior rental housing, and accounted for a small proportion of the variance in the dependent variable. Since affordability was the biggest concern among residents in senior housing, it was of significance that long-term housing affordability was ensured and reduction in service cost by utilizing economies of scale was pursued.
\end{abstract}

Keywords : The Elderly, Residential Satisfaction, Senior Housing, Independent Living Arrangement, Residential Supportiveness, Aging in Place

\section{INTRODUCTION}

Aging is full of transitions accompanied by social, economic, and psychological changes. Life disruptions such as retirement, bereavement and aging-related chronic diseases result in older adults facing fixed or shrinking financial resources. Adequate and affordable housing becomes a central concern of their lives. While well-off elderly people have multiple choices of housing options, those with limited income have few choices. The changes that occur with aging require the elderly to reassess their residential environments. In fact, the residential environment is a pivotal support element of the elderly's lives (Lee, 2006, 2007a, 2007b, 2007c, 2009). First, a residential environment can support independent living and foster selfsufficiency for the elderly. Therefore, the residential environment needs to match the changing needs of the elderly. Second, residential satisfaction for the elderly is closely associated with life satisfaction, so that it affects their quality of life or a sense of well-being. Third, adequate, accessible and affordable housing allows them to utilize their resources and to continue to live an independent life. Thus, the provision of a supportive environment that enables the elderly to maintain their independence becomes a vital issue for the elderly. With all the importance, it is of particular interest to examine housing alternatives that are particularly designed and available for the elderly.

The purpose of this study was to examine the residential satisfaction of the elderly in two different types of independent living arrangements in U.S. - cooperativelyowned and rental multi-unit housing. The research objectives were to find out how satisfied the elderly residing in senior co-op housing and senior rental housing were with their current residential environment, and what the impor- tant factors affecting their satisfaction with senior living were.

\section{LITERATURE REVIEW}

(1) Physical Environments for the Elderly

A supportive environment for the elderly cannot be achieved simply by providing barrier-free housing. The physical components of residential environments for the elderly include physical accessibility and affordability in order to gain a greater degree of independence.

(1) Location and neighborhood: The majority of elderly people reside in metropolitan areas. In 2008, $80.6 \%$ of all elderly people lived in metropolitan areas while $19 \%$ lived in nonmetropolitan areas. Almost $65 \%$ of those living in metropolitan areas lived outside the principal cities while $35 \%$ did in principal cities (Administration on Aging, 2009; U.S. Department of Housing and Urban Development \& U.S. Department of Commerce, 2008).

Safety in the neighborhood is one of the growing concerns for the elderly. The elderly feel vulnerable to crime, and the feeling is augmented if the neighborhood deteriorates over time. Locating senior housing in a safe neighborhood where services the households headed by the elderly need are easily accessible helps alleviate the fear of being victimized. Increased fear of crime is associated with low status neighborhoods with high crime risk, and the perceived fear that comes from living in an unsafe neighborhood leads to low satisfaction of the elderly with their housing and neighborhood (Conahan, Silverstein, \& Fitzerald, 2004).

Location of senior housing in a safe neighborhood is closely related to a sense of security, and it heightens the accessibility of the neighborhood. Thus, easy access to 
services (e.g., shopping and banking) and other amenities within a neighborhood contributes to residential satisfaction (Cooper \& Rodman, 1994).

(2) Age-specific living arrangement: Age-specific housing is referred to as a residential environment that has been intentionally planned for exclusive occupancy of the elderly. In $2008,6.5 \%$ of the elderly lived in age-specific housing, and the percentage remarkably increased with age (Administration on Aging, 2009). Age-specific housing has two main characteristics - the physical proximity and the age homogeneity of the environment (Kart, 1997). Agespecific living arrangements or age-homogeneous housing has been criticized in that the elderly are purposely isolated from the world although they have a strong desire to remain connected to it. Nonetheless, planned age-specific residential accommodations have positive effects on quality of life. Kart (1997) mentioned that age-specific residential settings contribute to positive social, economic, and psychological consequences. The elderly in the living arrangement create a congenial atmosphere, share personal relationships, and deal with issues (e.g., crime, services, and activities) in a more efficient and effective way. Thus, they produce safe, stable, and supportive living environments.

Physical proximity is one of the most common features found in an age-specific living arrangement, and this communal living encourages the elderly to have social interaction among themselves. By the nature of group living, age-specific living arrangements are likely to produce more interaction among elderly residents. They interact and develop supportive relationships such as friendships and mutual support (Kart, 1997).

(3) Accessible housing with care-free living: Many of the elderly households live in old dwellings, and age of housing is also related to housing inadequacy. Approximately four-fifths $(80 \%)$ of the owner households in 1995 resided in single-family detached homes (Citro, 1998). In 2007 , the median built year of housing occupied by the elderly households in 2007 was 1969 and 4.4\% had physical problems while the median construction year of housing for all households was 1973 (Administration on Aging, 2009; U.S. Department of Housing and Urban Development \& U.S. Department of Commerce, 2008).

Older housing coupled with the elderly's limited income sources and debilitating physical abilities can cause environmentally induced handicaps for the elderly households headed. As the incidence of physical limitations increases with age, accessible housing is needed. Administration on Aging (2009) reported that $38 \%$ of elderly persons in 2008 suffered from any sort of physical limitations (e.g., seeing, hearing, or performing any of the basic activities of daily living), which doesn't require particular assistance to meet important personal needs. However, more than one third of elderly persons (37\%) in 2005 had severe physical limitations, and 16\% needed compensating modifications (Administration on Aging, 2009; U.S. Department of Housing and Urban Development \& U.S. Department of Commerce, 2008).
Accessible housing does enable the households headed by the elderly to live more independently and to improve their quality of life than in housing that is not barrier-free (Addae-Dapaah \& Wong, 2001; Bechtel, 1997; Kahana, Lovegreen, Kahana \& Kahana, 2003). The residential environment that is accessible increases performance levels of daily activities for the elderly (Leibrock \& Terry, 1999). Thus, the design and construction requirements allow the elderly to enjoy and use their own dwellings as well as public areas safely and to enhance their capability to live independently.

(4) Affordable housing: The elderly households who tend to have a smaller household size and shrinking income resources are likely to be shelter-poor. In addition, housing affordability becomes a critical concern as the elderly age in that the spending for medical care in advancing years dramatically increases. About 3.7 million elderly persons $(9.7 \%)$ suffered from poverty in 2008 , and 2.4 million $(6.3 \%)$ were considered as near-poor (Administration on Aging, 2009; U.S. Department of Housing and Urban Development \& U.S. Department of Commerce, 2008).

The elderly households who are renters spend more on housing than homeowners do. According to Administration on Aging (2009), 46\% of elderly households in 2007 spent more than one fourth of their income on housing costs, and out of them, $39 \%$ were homeowners while $73 \%$ for renters. The elderly who are female and live alone are more likely to be inflicted by poverty than any other types. Female elderly persons in poverty were $11.9 \%$ while their male counterpart was $6.7 \%$. Also, $17.1 \%$ of elderly persons living alone were poor while only $3 \%$ lived with families.

\section{(2) Social Environment for the Elderly}

The supportive environment designed to enhance the independence level of the elderly includes not only physical characteristics but also social factors as a critical component. Generally speaking, social factors depend on the nature of each type of housing option. To the extent that the designed physical characteristics of the environment influence the social environment, every senior housing option has a different emphasis on creating unique social amenities, so that it is difficult to use uniform social factors that are applied for senior housing options. However, this section reviews the social factors that are most relevant to senior housing for independent living.

(1) Supportive services: Each type of senior housing option provides different levels of services, and the degree of the service depends on the independence level of the residents. Most senior housing for the independent elderly people provides limited and basic services also known as supportive services. Supportive services are designed to provide functional support, and defined as assisting basic tasks of daily living. Generally, they include transportation, meal services, housekeeping, and laundry. In other words, for the elderly with minor limitations who have a moderate level of ability or competence, as long as the environmental demand is moderately low, independence can be maintained and constant supervision was not needed (Lee, 
2003). Therefore, provision of some on-site services occurs when the needs or services of the elderly are not adequate in the proximity of the housing or require more convenience. Moving to age-specialized settings is typically predicted by lack of the resources to allow the elderly to stay at home and the decision to move is prompted by the elderly who are reluctant to be alone and need meal or residential services such as housekeeping (Conahan, Silverstein, \& Fitzerald, 2004; Lee, 2004). Most senior housing options for the independent elderly people offer few services that support tasks needing on-going supervision or medical care.

(2) Social support: Age-related life events such as chronic illness and loss of spouse often lead to stress which in turn affects psychological well-being (Cohen, 2004; Lubben, Rubinstein, \& Mintzer, 1994; Shaw, 2005). Social support is one of the adaptive strategies to improve physical and psychological functioning. Therefore, social support at a practical level includes exchanges of emotional concern, information and instrumental assistance, and becomes a key health-enhancing aspect of relationships (Adams, 1993; Cohen, 2004).

Social support involves informal patterns of both functional and emotional support, and they are more likely to be nurtured in homogeneous and comparable groups of people as well as communal living. Social integration is more likely to occur in a group of socially and economically comparable people and it develops companionships and maintains friendships. In fact, well-being for the elderly is positively affected by social activities (Baker, Cahalin, Gerst, \& Burr, 2005). For the elderly, participation in leisure and social activities is more likely to precipitate unplanned social interaction and communication.

(3) Resident-controlled Management Environment for the Elderly

Aging process is often accompanied with new adjustment to environmental contexts. To achieve successful aging, a residential environment ensures empowerment by rendering a sense of control. In other words, the control over residential environment at a broader level leads to psychological and political empowerment. According to Bratt (1991), political empowerment in living environments embraces the ability to control and make a decision on it while the psychological sense of empowerment is control over a variety of situations in their living environment. Therefore, such factors as control over residential environment, community involvement, and homeownership are important to provide quality of life in the course of aging.

(1) Control over residential environment: Physical change due to aging leads to some loss or reduction of control over surroundings. From the viewpoint that control is an intrinsic state of competency, a sense of control in later life is extremely important.

For the elderly, a sense of control over the residential environment becomes a vital part of their lives as physical functioning declines and the relative physical dependence on caregivers increases. In addition, the control over social environment is more important in explaining quality of life than physical environment (Cooper \& Rodman, 1994). Therefore, the perceived social control over the residential environment has more importance than the actual physical control. The sense of control over the residential environment can be achieved by participation in taking care of the property. The sense of control has a strong positive impact on abilities of the elderly to maintain their health and independence, and it is a key part of successful aging (Clark, et al, 1997; James, 2007). The ability gives them the perception of continued personal capabilities, and it reduces a sense of loss after life disruptions such as retirement and loss of spouse (Wasylishyn \& Johnson, 1998).

(2) Community involvement: Community involvement or community participation is a route to empowerment, and the grassroots approach is adopted where individuals living in the same geographic community act collectively on a particular issue or interests (Miller, Rein, \& Levitt, 1995). Community involvement allows empowerment to occur, and it includes the process or activities influencing the residential environment. Therefore, for the elderly, community involvement is viewed as participation in decision-making, and it is a step to identify needs or choice of options in a community (Onyx \& Benton, 1995). On the other hand, involvement in a community has specific roles and activities, and it describes duties and responsibilities in a setting (Frey, 2000; Prosper, 2000).

Community involvement is referred to as a sense of belonging and togetherness. For the elderly, involvement in a community means a sense of "being needed," and creates a caring community. Community-related activities through decision-making include giving voice on management, monitoring operations, enforcing rules, establishing grievance processes, and making decisions on necessary services. The participation in a community brings about positive effects on not only the environment but also the participants. The activities that stem from community involvement can contribute meaningful role opportunities and it leads to a sense of community.

(3) Homeownership: Homeownership includes economic, psychological and social investments of housing, and it contributes to neighborhood stability. Homeowners have greater involvement in neighborhood social networks than do renters. The establishment of close, social relationships with neighbors in the community has positive effects on neighborhoods. Homeownership increases the length of residency, improves values and physical conditions of property, and stabilizes social conditions in neighborhoods (Elsinga \& Hoekstra, 2005; Rohe \& Stewart, 1996). Therefore, homeownership produces an opportunity to participate in community activities, have social interactions with neighbors and attachment to the community, and have greater control over and maintain their dwelling units than renters. Since homeowners develop a sense of community, it is likely that they have a high level of residential satisfaction, and homeownership contributes to their sense of control. 
Homeownership rate rapidly increases with the age of householder. The elderly households are the group with the highest homeownership rate (Metropolitan Area Agency on Aging, 2005; Rossi \& Weber, 1996). The homeownership rate among elderly households in 2007 was $80 \%$, and about $68 \%$ of elderly homeowners owned their housing free and clear (Administration on Aging, 2009; U.S. Department of Housing and Urban Development \& U.S. Department of Commerce, 2008). However, the percentage of homeowners among the elderly households significantly decreases with advancing age. Of the elderly households, the cohort of 62 to 74 years old had the highest homeownership (81.2\%), followed by a 55 to 61 year-old cohort (78.8\%), 75 to $84(76.9 \%)$, and 85 and older (66.1\%) (U.S. Dept. of Housing and Urban Development, 2000).

\section{METHOD}

A questionnaire survey was conducted to achieve the research objectives of this study. Since the sampling frame wasn't available, a full list of the two types of housing was made. As with the selection of the comparison groups in a reasonable way is significant, the six housing developments in three sets of senior living arrangements for inde- pendent living were carefully selected based on physical characteristics (e.g., location, estate size, building age, building height, basic service features) and other considerations like amenities (Table 1).

Utilizing a nonprobability sampling method, the constructed sampling frame was drawn from a list of independent living arrangements. Based on the previous studies in the literature review, the research questionnaire was constructed, and the structured instrument was reviewed by a panel of six professionals in gerontology and housing studies. The questionnaire form that was revised after the pilot study was disseminated in two types of senior living arrangements in three counties of the metropolitan statistical areas in Minnesota with an increasing number of senior co-op housing and senior rental housing that was equipped with special features for the elderly. Out of 521 questionnaire packets distributed in the six senior housing complexes selected for the main survey that was implemented from 2002 to 2003 , a total of 280 completed responses $(53.7 \%)$ by mail were used for data analysis utilizing the Statistical Package for the Social Sciences (SPSS) for Windows. The statistical analyses included descriptive analysis, t-test, chi-square $\left(\chi^{2}\right)$ test, Pearson correlation coefficients, and multiple regression analysis.

Table 1. Description of the Studied Senior Housing Developments

\begin{tabular}{|c|c|c|c|c|c|c|c|c|c|c|}
\hline Category & Type & Location & County & $\begin{array}{l}\text { Year } \\
\text { built }\end{array}$ & $\begin{array}{l}\text { Minimum age } \\
\text { for occupancy }\end{array}$ & $\begin{array}{c}\text { Building } \\
\text { story }\end{array}$ & $\begin{array}{l}\text { No. of } \\
\text { Units }\end{array}$ & $\begin{array}{c}\text { Bedroom } \\
\text { types available }\end{array}$ & $\begin{array}{c}\text { Floor plan styles } \\
\text { available }\end{array}$ & $\begin{array}{c}\text { Response } \\
\operatorname{rate}(\%)\end{array}$ \\
\hline \multirow[b]{2}{*}{ I } & Co-op & Eagan & Dakota & 2001 & 62 & 3 & 69 & One to Three & 8 & 56.5 \\
\hline & Rental & Apple Valley & Dakota & 2001 & 60 & 3 & 60 & $\begin{array}{l}\text { Efficiency, } \\
\text { One \& Two }\end{array}$ & 7 & 46.7 \\
\hline \multirow[b]{2}{*}{ II } & Co-op & Eden Prairie & Hennepin & 1999 & 55 & 4 & 94 & One to Two & 15 & 65.9 \\
\hline & Rental & Bloomington & Hennepin & 1999 & 55 & 4 & 88 & $\begin{array}{l}\text { Efficiency, } \\
\text { One \& Two }\end{array}$ & 13 & 42.1 \\
\hline III & Rental & Blaine & Anoka & 2000 & 55 & 3 & 102 & $\begin{array}{l}\text { Efficiency, } \\
\text { One \& Two }\end{array}$ & 10 & 42.2 \\
\hline
\end{tabular}

\section{RESULTS}

(1) Demographics and Housing Characteristics of Respondents

The age of the participants in the study ranged from 55 to 91 (Table 2). The average age for the rental respondents $(M=75.6$ years) were slightly older than co-op respondents $(\mathrm{M}=75.1$ years $)$, and a t-test showed a significant difference in age of respondent between two housing types, $\mathrm{t}(7.521)=0.591, \mathrm{p}=.007$.

The respondents regardless of housing types were predominantly female. The percentage of the female respondents was higher in rental housing $(74.1 \%)$ than in coop housing $(56.7 \%)$.

The respondents were highly educated, and co-op respondents were more likely to have post-secondary education background $(67.8 \%)$ than rental respondents (48.2\%). Most of the co-op and rental respondents report their cur- rent income was adequate ( $88.3 \%$ and $75 \%$, respectively). Regardless of senior housing types, the great majority of the respondents were not employed although only a few were employed in any form.

The vast majority of both types of the respondents were not certain about their health status. The uncertainty in health was somewhat higher among co-op residents $(81.3 \%)$ than their counterparts $(65.7 \%)$ while the number of residents who considered health as poor was higher among rental residents $(24.1 \%)$ than co-op residents $(13.5 \%)$.

Two types of communities in the study had relatively different length, and the difference was statistically significant (Table 3). The length of building occupancy varied from 11 months to 2 years and 9 months, and the mean length is 23 months. The length of the co-op housing was likely to be longer ( $M=23.6$ months) than the one of the rental housing $(\mathrm{M}=22.9$ months $)$. 
Table 2. Distribution of Respondents' Demographics

\begin{tabular}{|c|c|c|}
\hline Characteristics $^{\mathrm{a}}$ & $\begin{array}{c}\text { Co-op } \\
(\mathrm{N}=171)\end{array}$ & $\begin{array}{c}\text { Rental } \\
(\mathrm{N}=109)\end{array}$ \\
\hline $\begin{array}{l}\text { Age of respondent } * * \\
\text { Mdn } \\
\text { M } \\
\text { SD } \\
\text { Range (from minimum to maximum) }\end{array}$ & $\begin{array}{c}75.0 \\
75.1 \\
6.2 \\
59 \text { to } 88\end{array}$ & $\begin{array}{c}76.0 \\
75.6 \\
7.9 \\
55 \text { to } 91\end{array}$ \\
\hline $\begin{array}{l}\text { Gender of respondent** } \\
\text { Male } \\
\text { Female } \\
\text { Missing }\end{array}$ & $\begin{array}{r}71(41.5 \%) \\
97(56.7 \%) \\
3(1.8 \%)\end{array}$ & $\begin{array}{r}25(23.1 \%) \\
81(74.1 \%) \\
3(2.8 \%)\end{array}$ \\
\hline $\begin{array}{l}\text { Education of respondent } * \\
\text { Less than } 9^{\text {th }} \text { grade } \\
\text { Some high school } \\
\text { High school/GED } \\
\text { Some college } \\
\text { College graduate } \\
\text { Graduate degree } \\
\text { Missing }\end{array}$ & $\begin{array}{r}2(1.2 \%) \\
9(5.3 \%) \\
43(25.1 \%) \\
48(28.1 \%) \\
38(22.2 \%) \\
30(17.5 \%) \\
1(0.6 \%)\end{array}$ & $\begin{array}{r}2(1.9 \%) \\
10(9.3 \%) \\
44(40.7 \%) \\
29(26.9 \%) \\
15(13.9 \%) \\
8(7.4 \%) \\
0(0.0 \%)\end{array}$ \\
\hline $\begin{array}{l}\text { Income adequacy } * \\
\text { Adequate } \\
\text { Inadequate } \\
\text { Not certain } \\
\text { Missing }\end{array}$ & $\begin{array}{r}151(88.3 \%) \\
7(4.1 \%) \\
12(7.0 \%) \\
1(0.6 \%)\end{array}$ & $\begin{array}{r}82(75.2 \%) \\
9(8.3 \%) \\
18(16.5 \%) \\
0(0.0 \%)\end{array}$ \\
\hline $\begin{array}{l}\text { Employment status of respondent } \\
\text { Employed }^{\text {b }} \\
\text { Not employed } \\
\text { Missing }\end{array}$ & $\begin{array}{r}22(12.9 \%) \\
148(86.5 \%) \\
1(0.6 \%)\end{array}$ & $\begin{array}{r}17(15.7 \%) \\
92(84.3 \%) \\
0(0.0 \%)\end{array}$ \\
\hline $\begin{array}{l}\text { Health status of respondent * } \\
\text { Healthy } \\
\text { Not certain } \\
\text { Poor } \\
\text { Missing }\end{array}$ & $\begin{array}{r}8(4.7 \%) \\
139(81.3 \%) \\
23(13.5 \%) \\
1(0.6 \%)\end{array}$ & $\begin{array}{r}10(9.3 \%) \\
72(65.7 \%) \\
26(24.1 \%) \\
1(0.9 \%)\end{array}$ \\
\hline
\end{tabular}

Note: ${ }^{\text {a }}$ Tests of significance were t-test for ages of respondent, and $\chi^{2}$ test

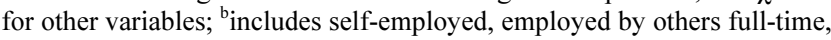
part-time, and both full- \& part-time, $* \mathrm{p}<.05, * * \mathrm{p}_{-}<.01$

Table 3. Distribution of Housing Characteristics of Respondents

\begin{tabular}{|c|c|c|}
\hline Characteristics $^{\mathrm{a}}$ & $\begin{array}{c}\text { Co-op } \\
(\mathrm{N}=171)\end{array}$ & $\begin{array}{c}\text { Rental } \\
(\mathrm{N}=108)\end{array}$ \\
\hline $\begin{array}{l}\text { Length of building occupancy (month)* } \\
\text { Mdn } \\
\text { M } \\
\text { SD } \\
\text { Range (from minimum to maximum) }\end{array}$ & $\begin{array}{c}25.8 \\
23.6 \\
7.2 \\
11 \text { to } 30\end{array}$ & $\begin{array}{c}23.4 \\
23.0 \\
8.5 \\
11 \text { to } 33\end{array}$ \\
\hline $\begin{array}{l}\text { Number of bedroom } * * * \\
\text { Studio } \\
\text { One bedroom } \\
\text { Two bedroom } \\
\text { Three bedroom }\end{array}$ & $\begin{array}{r}0(0.0 \%) \\
28(16.4 \%) \\
141(82.5 \%) \\
2(1.2 \%)\end{array}$ & $\begin{array}{r}4(3.7 \%) \\
64(58.7 \%) \\
41(37.6 \%) \\
0(0.0 \%)\end{array}$ \\
\hline $\begin{array}{l}\text { Housing duration (month) } \\
\text { Mdn } \\
\text { M } \\
\text { SD } \\
\text { Range (from minimum to maximum) }\end{array}$ & $\begin{array}{c}22.5 \\
19.0 \\
8.4 \\
1.5 \text { to } 36\end{array}$ & $\begin{array}{c}20.1 \\
18.8 \\
8.9 \\
2.0 \text { to } 42\end{array}$ \\
\hline
\end{tabular}

Number of bedrooms in current housing ranged from studio style to three bedrooms. The co-op residents were more likely to consume large size of housing than rental residents do. The vast majority of the co-op respondents lived in two-bedroom $(82.5 \%)$ while the rental respondents in one-bedroom comprised the largest grouping (58.7\%).
Housing duration varied from one and half months to three and half years. The duration between two groups wasn't statistically significant.

\section{(2) Indices of Current Senior Living}

Current senior living were divided into three indices consisting of twelve items; satisfaction with physical environment, social environment, and resident-controlled management. The index of physical environment consisted of location and neighborhood, communal living, care-free living, accessibility, and affordability (Table 4). Out of the items for index of physical environment, location of housing and neighborhood and accessibility were highest in satisfaction for both co-op and rental residents. There was no statistically significant difference of satisfaction with the five physical environment items between co-op and rental groups. It implies that the elderly are likely to consider their housing choice based on the aging-related needs that are more crucial than any other factors.

Table 4. Percentage Distribution of Items According to Indices of Current Senior Living

\begin{tabular}{|c|c|c|c|c|}
\hline \multirow[b]{2}{*}{ Category } & \multicolumn{2}{|c|}{ Co-op } & \multicolumn{2}{|c|}{ Rental } \\
\hline & $\begin{array}{l}\text { Number } \\
(\mathrm{N}=171)\end{array}$ & $\begin{array}{l}\text { Percentage } \\
(100 \%)\end{array}$ & $\begin{array}{l}\text { Number } \\
(\mathrm{N}=109)\end{array}$ & $\begin{array}{l}\text { Percentage } \\
(100 \%)\end{array}$ \\
\hline \multicolumn{5}{|c|}{ Index of Physical Environment } \\
\hline Accessibility & 162 & 94.7 & 104 & 95.4 \\
\hline $\begin{array}{l}\text { Location and neighbor- } \\
\text { hood }\end{array}$ & 162 & 94.7 & 104 & 95.4 \\
\hline Care-free living & 160 & 93.6 & 102 & 93.6 \\
\hline Affordability & 147 & 86.0 & 99 & 90.8 \\
\hline Communal living & 137 & 80.1 & 85 & 78.0 \\
\hline \multicolumn{5}{|c|}{ Index of Social Environment } \\
\hline Social activities & 140 & 81.9 & 82 & 75.2 \\
\hline Supportive services & 101 & 59.1 & 80 & 73.4 \\
\hline \multicolumn{5}{|c|}{ Index of Resident-controlled Management Environment } \\
\hline $\begin{array}{l}\text { Keeping housing cost } \\
\text { affordable }\end{array}$ & 144 & 84.2 & 87 & 79.8 \\
\hline Democratic control** & 139 & 81.5 & 62 & 56.9 \\
\hline A sense of community & 138 & 80.7 & 69 & 63.3 \\
\hline $\begin{array}{l}\text { Control over the prop- } \\
\text { erty*** }\end{array}$ & 138 & 80.7 & 55 & 50.5 \\
\hline $\begin{array}{l}\text { Participation in com- } \\
\text { munity }\end{array}$ & 114 & 66.7 & 62 & 56.9 \\
\hline
\end{tabular}

Note: Only satisfaction is regarded here, not responses of neither or dissatisfied.

$* * \mathrm{p}<.01, * * * \mathrm{p}<.001$

Supportive services and social activities were included in the index of social environment. A relatively higher percentage of satisfaction with social activities was reported for co-op residents while the higher number of satisfaction with supportive services was found among rental residents. However, no statistical significance of satisfaction of the two components of social environment between co-op and rental residents was salient. It indicates that social activities and support services which uphold the index of social environment are important to the elderly's life.

Five items were included in the index of residentcontrolled management - keeping housing cost affordable, democratic control, control over the property, participation 
in community, and a sense of community. Of the specified items of satisfaction with resident-controlled management, two items were significantly different between two groups; democratic control, $\chi^{2}(2, \mathrm{~N}=247)=10.227$, $\mathrm{p}=.006$; and control over the property, $\chi^{2}(2$, $\mathrm{N}=245)=15.849, \mathrm{p}=.000$. Co-op residents were more likely to be satisfied with democratic control and control over the property. It is related to the governing structure that is uniquely found in co-op housing and further is distinguished from rental housing.

Through the three-point scale reduction (from dissatisfied to neither to satisfied), the percentage distribution of satisfaction of each index of which the clustered items were recomputed was presented in Table 5. The majority of co-op and rental residents were satisfied with physical and social environments, but the percentage of satisfaction with resident-controlled management was lower among rental residents than among co-op residents although the statistical difference of two groups was not significant.

With regard to satisfaction with resident-controlled management, the concerns of co-op respondents were different from those of rental respondents. Little voice in management was given to rental residents, and the role of rental residents in relation to control over the residential environment was very limited and passive, often challenging. Contrary to rental residents, co-op residents had a strong voice in management, which causes a major distinction between the two senior housing types.

Regardless of senior housing types, the residents were overall satisfied with their current residential environment, and satisfaction with each index of current senior living was not as high as seen in the overall satisfaction (Table 6).
Table 5. Percentage Distribution of Three Satisfaction Indices of Current Senior Living

\begin{tabular}{|c|c|c|c|c|}
\hline \multirow[b]{2}{*}{ Index } & \multicolumn{2}{|c|}{ Co-op } & \multicolumn{2}{|c|}{ Rental } \\
\hline & $\begin{array}{l}\text { Number } \\
(\mathrm{N}=171)\end{array}$ & $\begin{array}{c}\text { Percentage } \\
(100 \%)\end{array}$ & $\begin{array}{l}\text { Number } \\
(\mathrm{N}=109)\end{array}$ & $\begin{array}{c}\text { Percentage } \\
(100 \%)\end{array}$ \\
\hline \multicolumn{5}{|c|}{ Satisfaction with Physical Environment } \\
\hline Satisfied & 118 & 69.0 & 75 & 68.8 \\
\hline Neither & 26 & 15.2 & 17 & 15.6 \\
\hline Dissatisfied & 16 & 9.4 & 5 & 4.6 \\
\hline Missing & 11 & 6.4 & 12 & 11.0 \\
\hline \multicolumn{5}{|c|}{ Satisfaction with Social Environment } \\
\hline Satisfied & 94 & 55.0 & 69 & 63.3 \\
\hline Neither & 37 & 21.6 & 22 & 20.2 \\
\hline Dissatisfied & 4 & 2.3 & 3 & 2.8 \\
\hline Missing & 36 & 21.1 & 15 & 13.8 \\
\hline \multicolumn{5}{|c|}{ Satisfaction with Resident-controlled Management } \\
\hline Satisfied & 98 & 57.3 & 40 & 36.7 \\
\hline Neither & 35 & 20.5 & 27 & 24.8 \\
\hline Dissatisfied & 15 & 8.8 & 12 & 11.0 \\
\hline Missing & 23 & 13.5 & 30 & 27.5 \\
\hline
\end{tabular}

Table 6. Percentage Distribution of Overall Satisfaction with Current Residential Environment

\begin{tabular}{l|cc|cc}
\hline \multirow{4}{*}{ Characteristics } & \multicolumn{2}{|c|}{ Co-op } & \multicolumn{2}{c}{ Rental } \\
\cline { 2 - 5 } & Number & Percentage & Number & Percentage \\
& $(\mathrm{N}=171)$ & $(100 \%)$ & $(\mathrm{N}=109)$ & $(100 \%)$ \\
\hline Satisfied & 158 & 92.4 & 101 & 92.7 \\
Neither & 6 & 3.5 & 5 & 4.6 \\
Dissatisfied & 7 & 4.1 & 3 & 2.8 \\
\hline
\end{tabular}

(3) Effects of Demographics and Housing Characteristics on Satisfaction Indices of Current Senior Living

Table 7. Pearson Product-moment Coefficient Matrix for Variables Selected for Co-op Residents (N=171)

\begin{tabular}{|c|c|c|c|c|c|c|c|c|c|c|c|c|c|c|c|}
\hline & & 1 & 2 & 3 & 4 & 5 & 6 & 7 & 8 & 9 & 10 & 11 & 12 & 13 & 14 \\
\hline 1 & Age & 1.000 & & & & & & & & & & & & & \\
\hline 2 & Gender & $-.245^{*}$ & 1.000 & & & & & & & & & & & & \\
\hline 3 & Household type & -.064 & $.484 * *$ & 1.000 & & & & & & & & & & & \\
\hline 4 & Education & .132 & $.238 * *$ & .080 & 1.000 & & & & & & & & & & \\
\hline 5 & Income adequacy & .140 & $-.156^{*}$ & -.053 & -.063 & 1.000 & & & & & & & & & \\
\hline 6 & Employment status & $-.265 * *$ & $-.204 * *$ & -.138 & -.043 & .014 & 1.000 & & & & & & & & \\
\hline 7 & Health status & -.071 & -.067 & -.044 & -.029 & .144 & -.002 & 1.000 & & & & & & & \\
\hline 8 & Year built & -.006 & .082 & .053 & .105 & -.017 & .007 & -.111 & 1.000 & & & & & & \\
\hline 9 & Number of bedroom & .018 & $-.245 * *$ & $-.274 * *$ & $-.166^{*}$ & .131 & .016 & .061 & -.068 & 1.000 & & & & & \\
\hline 10 & Duration & -.005 & .062 & .058 & .015 & -.005 & -.117 & $-.160 *$ & .013 & $.684 * *$ & 1.000 & & & & \\
\hline 11 & $\begin{array}{l}\text { Satisfaction of physical } \\
\text { environment }\end{array}$ & $.208 * *$ & .020 & .075 & .111 & $.199 *$ & .063 & -.128 & -.062 & -.040 & -.027 & 1.000 & & & \\
\hline 12 & \begin{tabular}{|l|l|}
$\begin{array}{l}\text { Satisfaction of social } \\
\text { environment }\end{array}$ \\
\end{tabular} & .205 & -.019 & .127 & $.216^{*}$ & .128 & -.027 & .038 & -.038 & -.138 & .080 & $.461 * *$ & 1.000 & & \\
\hline 13 & $\begin{array}{l}\text { Satisfaction of resident- } \\
\text { controlled management }\end{array}$ & .139 & -.002 & .013 & $.169 *$ & $.240 * *$ & .017 & -.105 & -.019 & .087 & .056 & $.689 * *$ & $.326 * *$ & 1.000 & \\
\hline 14 & $\begin{array}{l}\text { Overall residential } \\
\text { satisfaction }\end{array}$ & $.162 *$ & -.049 & .038 & .040 & $.275 * *$ & -.099 & .052 & -.026 & .007 & .010 & $.226 * *$ & .105 & $.426 * *$ & 1.000 \\
\hline
\end{tabular}

Note: $* \mathrm{p}<.05, * * \mathrm{p}<.01$ (2-tailed test) 
Table 8. Pearson Product-moment Coefficient Matrix for Variables Selected for Rental Residents (N=109)

\begin{tabular}{|c|c|c|c|c|c|c|c|c|c|c|c|c|c|c|c|}
\hline & & 1 & 2 & 3 & 4 & 5 & 6 & 7 & 8 & 9 & 10 & 11 & 12 & 13 & 14 \\
\hline 1 & Age & 1.000 & & & & & & & & & & & & & \\
\hline 2 & Gender & -.140 & 1.000 & & & & & & & & & & & & \\
\hline 3 & Household type & $-.287 * *$ & $.439 * *$ & 1.000 & & & & & & & & & & & \\
\hline 4 & Education & -.024 & .152 & .054 & 1.000 & & & & & & & & & & \\
\hline 5 & Income adequacy & .067 & -.162 & $-.215^{*}$ & .048 & 1.000 & & & & & & & & & \\
\hline 6 & Employment status & $-.430 * *$ & .113 & .140 & -.086 & -.136 & 1.000 & & & & & & & & \\
\hline 7 & Health status & $-.247 *$ & .103 & .183 & -.018 & .090 & $.298 * *$ & 1.000 & & & & & & & \\
\hline 8 & Year built & $.410 * *$ & -.032 & $-.320 * *$ & -.090 & $.212 *$ & $-.212^{*}$ & $-.256^{* *}$ & 1.000 & & & & & & \\
\hline 9 & Number of bedroom & $.190^{*}$ & -.089 & $-.402 * *$ & -.005 & .036 & -.131 & -.136 & .130 & 1.000 & & & & & \\
\hline 10 & Duration & .164 & .024 & -.145 & -.126 & .129 & -.090 & -.167 & -.044 & $.573 * *$ & 1.000 & & & & \\
\hline 11 & $\begin{array}{l}\text { Satisfaction of physical } \\
\text { environment }\end{array}$ & .059 & -.061 & -.061 & -.056 & .114 & .046 & -.027 & .063 & .004 & -.026 & 1.000 & & & \\
\hline 12 & $\begin{array}{l}\text { Satisfaction of social } \\
\text { environment }\end{array}$ & .081 & .067 & .003 & .037 & .203 & .064 & -.017 & . 146 & -.005 & -.169 & $.576^{* *}$ & 1.000 & & \\
\hline 13 & $\begin{array}{l}\text { Satisfaction of resident- } \\
\text { controlled management }\end{array}$ & -.001 & .065 & .100 & .154 & .155 & .136 & -.011 & -.056 & -.117 & -.173 & $.664 * *$ & $.320 * *$ & 1.000 & \\
\hline 14 & $\begin{array}{l}\text { Overall residential } \\
\text { satisfaction }\end{array}$ & .061 & 190 & -.030 & .101 & .024 & .095. & -.059 & -.023 & .081 & .097. & $.571 * *$ & $.378^{* *}$ & $.438^{*}$ & 1.000 \\
\hline
\end{tabular}

Note: $* p<.05,{ }^{* *} p<.01$ (2-tailed test)

To find out the relationship among demographic and housing variables, three indices of current senior living, and overall residential satisfaction, a multiple regression analysis was utilized. Before the regression analysis was conducted, Pearson correlation coefficients among all the selected variables were computed in order to see the overall effect of the predictors on the dependent variables and to detect multicollinearity among the variables. Correlation matrixes for the 14 variables selected in this research were presented in Table 7 and 8. All of the coefficient values among exogenous variables were no greater than .7, and didn't present a serious multicollinearity effect.

(1) Effects of Demographics and Housing Characteristics on Satisfaction Index of Current Physical Environment: As illustrated in Table 9, the exogenous variables of the specified demographics as a group were significantly associated with satisfaction index of physical environment among co-op residents, but not among rental residents. For a co-op group, age and income adequacy had significant and positive effects on the satisfaction index ( $p=.016$ and $\mathrm{p}=.011$, respectively). Also employment status and health status were important to the explanation of satisfaction index of physical environment at the $\mathrm{p}<.10$ level. The co-op residents who were older and have adequate income to meet their needs were more likely to be satisfied with their current senior living.

The exogenous variables of the specified housing variables entered as a block didn't have any significant relationship with satisfaction index of physical environment among co-op and rental residents (Table 10). None of the exogenous variables were significantly related to the satisfaction index.
Table 9. Summary of Regression Analysis for Demographic Variables Predicting Satisfaction Index of Current Physical Environment

\begin{tabular}{|c|c|c|c|c|c|c|}
\hline Variables & B & $\begin{array}{c}\text { Co-op } \\
\text { SE }\end{array}$ & Beta & $\mathrm{B}$ & $\frac{\text { Rental }}{\text { SE }}$ & Beta \\
\hline (Constant) & 2.417 & .192 & & 2.892 & .158 & \\
\hline Age & .005 & .002 & $.218^{*}$ & .001 & .002 & .065 \\
\hline Gender & .022 & .032 & .071 & -.006 & .029 & -.025 \\
\hline $\begin{array}{l}\text { Household } \\
\text { type }\end{array}$ & .024 & .028 & .077 & -.003 & .031 & -.013 \\
\hline Education & .024 & .027 & .076 & -.014 & .027 & -.055 \\
\hline $\begin{array}{l}\text { Income } \\
\text { adequacy }\end{array}$ & .068 & .026 & $.205^{*}$ & .019 & .018 & .114 \\
\hline $\begin{array}{l}\text { Employment } \\
\text { status }\end{array}$ & .068 & .039 & .148 & .028 & .034 & .100 \\
\hline Health status & -.051 & .029 & -.136 & -.004 & .021 & -.022 \\
\hline$<.05$ & $\begin{array}{l}2=.1 \\
(7,1\end{array}$ & adj. & $=.005$ & $\begin{array}{l}2=.0 \\
(7,8\end{array}$ & ${ }_{\text {adj. }}=$ & $\begin{array}{l}4 \\
935\end{array}$ \\
\hline
\end{tabular}

Table 10. Summary of Regression Analysis for Housing Variables Predicting Satisfaction Index of Current Physical Environment

\begin{tabular}{|c|c|c|c|c|c|c|}
\hline Variables & B & $\frac{\text { Co-op }}{\text { SE }}$ & Beta & B & $\frac{\text { Rental }}{\text { SE }}$ & Beta \\
\hline (Constant) & 3.072 & .103 & & 2.967 & .052 & \\
\hline Year built & -.001 & .002 & -.050 & .000 & .002 & .016 \\
\hline $\begin{array}{l}\text { Number of } \\
\text { bedroom }\end{array}$ & -.026 & .032 & -.065 & .011 & .019 & .060 \\
\hline Duration & .000 & .002 & .008 & -.000 & .002 & -.034 \\
\hline & , 154) & 305 & 322 & $\begin{array}{l}2=.00 \\
(3,92\end{array}$ & $\begin{array}{l}\mathrm{R}_{\text {adj. }}= \\
.146, p\end{array}$ & \\
\hline
\end{tabular}

(2) Effects of Demographics and Housing Characteristics on Satisfaction Index of Current Social Environment: The equation predicting the relationship between demographic variables and satisfaction index of social environment was significant among co-op residents, but not 
among rental residents (Table 11). For a co-op group, education was a significant predictor in the equation $(\mathrm{p}=.034)$, and age appears to be somewhat an important variable $(\mathrm{p}=.073)$. The co-op residents who were older and had adequate in come were more likely to have a positive proposition in satisfaction index of social environment. Although the demographic variables as a group were not significantly related for a rental group to the assessment index, income had an important effect $(\mathrm{p}=.026)$.

Table 11. Summary of Regression Analysis for Demographic Variables Predicting Satisfaction Index of Current Social Environment

\begin{tabular}{|c|c|c|c|c|c|c|}
\hline \multirow[b]{2}{*}{ Variables } & \multirow[b]{2}{*}{ B } & \multirow{2}{*}{$\begin{array}{c}\text { Co-op } \\
\text { SE }\end{array}$} & \multirow[b]{2}{*}{ Beta } & \multirow[b]{2}{*}{$\mathrm{B}$} & \multirow{2}{*}{$\begin{array}{c}\text { Rental } \\
\text { SE }\end{array}$} & \multirow[b]{2}{*}{ Beta } \\
\hline & & & & & & \\
\hline (Constant) & 1.970 & .374 & & 1.869 & .500 & \\
\hline Age & .008 & .004 & .176 & .007 & .005 & .171 \\
\hline Gender & -.043 & .061 & -.074 & .031 & .096 & .039 \\
\hline $\begin{array}{l}\text { Household } \\
\text { type }\end{array}$ & .089 & .055 & .153 & .065 & .099 & .084 \\
\hline Education & .116 & .054 & $.194 *$ & .038 & .089 & .046 \\
\hline $\begin{array}{l}\text { Income } \\
\text { adequacy }\end{array}$ & .067 & .050 & .118 & .136 & .060 & $.250 *$ \\
\hline $\begin{array}{l}\text { Employment } \\
\text { status }\end{array}$ & .016 & .079 & .019 & .147 & .113 & .157 \\
\hline Health status & .033 & .059 & .048 & -.011 & .071 & -.017 \\
\hline 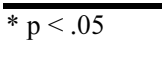 & $\begin{array}{l}\mathrm{R}^{2}=.112 \\
\mathrm{~F}(7,122\end{array}$ & 2 adj. $=$ & 039 & $\begin{array}{l}\mathrm{R}^{2}=.08 \\
(7,82)\end{array}$ & $\begin{array}{l}\mathrm{R}_{\text {adj. }}^{2}= \\
1.103\end{array}$ & $\begin{array}{l}8 \\
=.369\end{array}$ \\
\hline
\end{tabular}

The set of a regression analysis predicting satisfaction index of social environment from three housing variables was significant among co-op residents, but not among rental residents (Table 12). For a co-op group, the year current housing built and housing duration were significant variables in the equation $(\mathrm{p}=.001$, and $\mathrm{p}=.004$, respectively). Co-op residents who resided in relatively earlier built housing and lived longer were more likely to have satisfaction index of social environment.

Table 12. Summary of Regression Analysis for Housing Variables Predicting Satisfaction Index of Current Social Environment

\begin{tabular}{|c|c|c|c|c|c|c|}
\hline \multirow[b]{2}{*}{ Variables } & \multirow[b]{2}{*}{ B } & \multirow{2}{*}{$\begin{array}{c}\text { Co-op } \\
\text { SE }\end{array}$} & \multirow[b]{2}{*}{ Beta } & \multirow[b]{2}{*}{ B } & \multirow{2}{*}{$\frac{\text { Rental }}{\mathrm{SE}}$} & \multirow[b]{2}{*}{ Beta } \\
\hline & & & & & & \\
\hline (Constant) & 3.251 & .230 & & 2.771 & .184 & \\
\hline Year built & -.015 & .005 & $-.388 * * *$ & .004 & .005 & .108 \\
\hline $\begin{array}{l}\text { Number of } \\
\text { bedroom }\end{array}$ & -.073 & .069 & -.090 & .076 & .067 & .119 \\
\hline Duration & .012 & .004 & $.339 * *$ & -.009 & .005 & -.222 \\
\hline$* * * p<.001$ & $F(3,12$ & 4.00 & $\begin{array}{l}4 \\
=.009\end{array}$ & $\mathrm{~F}(3$, & 1.705 , & .172 \\
\hline
\end{tabular}

(3) Effects of Demographics and Housing Characteristics on Satisfaction Index of Current Resident-controlled Management: The relationship between seven demographic variables and satisfaction index of residentcontrolled management was statistically significant for coop residents, but not for rental residents (Table 13). For a co-op group, income was significantly associated with the satisfaction index $(\mathrm{p}=.002)$. Also education and health status had important effects on satisfaction index of resident- controlled management at the $\mathrm{p}<.10$ level.

Table 13. Summary of Regression Analysis for Demographic Variables Predicting Satisfaction Index of Current Resident-controlled Management

\begin{tabular}{|c|c|c|c|c|c|c|}
\hline \multirow[b]{2}{*}{ Variables } & \multirow[b]{2}{*}{ B } & \multirow{2}{*}{$\begin{array}{c}\text { Co-op } \\
\text { SE }\end{array}$} & \multirow[b]{2}{*}{ Beta } & \multirow[b]{2}{*}{ B } & \multirow{2}{*}{$\frac{\text { Rental }}{\mathrm{SE}}$} & \multirow[b]{2}{*}{ Beta } \\
\hline & & & & & & \\
\hline (Constant) & 2.308 & .347 & & 2.029 & .601 & \\
\hline Age & .004 & .004 & .099 & .006 & .006 & .124 \\
\hline Gender & .020 & .056 & .037 & .018 & .104 & .023 \\
\hline $\begin{array}{l}\text { Household } \\
\text { type }\end{array}$ & .008 & .050 & .015 & .101 & .112 & .124 \\
\hline Education & .088 & .047 & .161 & .111 & .094 & .143 \\
\hline $\begin{array}{l}\text { Income } \\
\text { adequacy }\end{array}$ & .146 & .047 & $.264 * *$ & .115 & .070 & .202 \\
\hline $\begin{array}{l}\text { Employment } \\
\text { status }\end{array}$ & .041 & .069 & .053 & .218 & .125 & .236 \\
\hline Health status & -.091 & .055 & -.136 & -.045 & .083 & -.068 \\
\hline$* \mathrm{p}<.01$ & $\begin{array}{l}\mathrm{R}^{2}=.115 \\
\mathrm{~F}(7,135\end{array}$ & 2.60 & 015 & $\begin{array}{l}2=.0 \\
(7,6\end{array}$ & $\begin{array}{l}R_{\text {adj. }}^{2}= \\
1.025\end{array}$ & 423 \\
\hline
\end{tabular}

The specified three housing variables as a group were not significantly related to satisfaction index of residentcontrolled management for both co-op and rental groups (Table 14). There were no exogenous variables that significantly contribute to the satisfaction index.

Table 14. Summary of Regression Analysis for Housing Variables Predicting Satisfaction Index of Current Resident-controlled Management

\begin{tabular}{|c|c|c|c|c|c|c|}
\hline \multirow[b]{2}{*}{ Variables } & \multirow[b]{2}{*}{ B } & \multirow{2}{*}{$\begin{array}{c}\text { Co-op } \\
\text { SE }\end{array}$} & \multirow[b]{2}{*}{ Beta } & \multirow[b]{2}{*}{ B } & \multirow{2}{*}{$\begin{array}{c}\text { Rental } \\
\text { SE }\end{array}$} & \multirow[b]{2}{*}{ Beta } \\
\hline & & & & & & \\
\hline (Constant) & 2.896 & .184 & & 3.127 & .200 & \\
\hline Year built & .003 & .004 & .090 & -.000 & .006 & -.010 \\
\hline $\begin{array}{l}\text { Number of } \\
\text { bedroom }\end{array}$ & -.010 & .058 & -.015 & -.042 & .073 & -.066 \\
\hline Duration & -.000 & .004 & -.006 & -.007 & .006 & -.172 \\
\hline & $F(3,14$ & $\begin{array}{l}{ }^{2} \text { adj. } \\
.367\end{array}$ & 13 & $\begin{array}{l}\mathrm{R}^{2}=.035 \\
\mathrm{~F}(3,73)\end{array}$ & $\begin{array}{l}\mathrm{R}_{\text {adj. }}^{2} \\
=.871,\end{array}$ & $\begin{array}{l}05 \\
.460\end{array}$ \\
\hline
\end{tabular}

(4) Effects of Demographics, Housing Characteristics, and Satisfaction Indices of Current Senior Living on Overall Satisfaction of Current Residential Environment

Regression analysis was conducted to predict the relationship among seven demographic characteristics, three housing characteristics, three satisfaction indices of current senior living, and overall satisfaction of current residential environment among co-op and rental residents. The regression results were summarized in Tables 15 and 16.

The relationship between the demographic variables and the overall satisfaction index of current senior living was significant for co-op residents but not for rental residents. Income adequacy among co-op residents was significant variable in the equation $(\mathrm{p}=.000)$, and gender among rental residents was significantly related to the index $(p=.039)$.

The second step of the regression analysis indicated that after holding the effects of the demographic variables constant, the housing variables entered as a block didn't account for a significant proportion of the satisfaction with 
current residential environment among both co-op and rental residents even though the equation with demographic and housing variables were still significant among co-op residents but not among rental residents. Income was a significant predictor in the equation for co-op residents $(\mathrm{p}=.000)$, and gender had somewhat a significant relationship with the index for rental residents $(\mathrm{p}=.050)$.

The final set showed that the three satisfaction indices of senior living significantly contributed to the overall sat- isfaction of current residential environment among both co-op and rental residents after controlling for the effects of the exogenous variables. For a co-op group, income adequacy was a significant variable in the equation $(p=.011)$. The analysis implied that co-op households with adequate income were more likely to have a positive effect on overall satisfaction of their current residential environment.

Table 15. Summary of Hierarchical Regression Analysis for Variables Predicting Current Residential Environment of Co-op Residents

\begin{tabular}{|c|c|c|c|c|c|c|c|c|c|}
\hline \multirow[b]{2}{*}{ Variables } & \multirow{2}{*}{$\begin{array}{c}\text { Step } 1 \\
\text { B }\end{array}$} & \multicolumn{2}{|c|}{ Demographics } & \multirow{2}{*}{$\begin{array}{r}\text { Step } 2 \\
\mathrm{~B}\end{array}$} & \multicolumn{2}{|c|}{ Housing Characteristics } & \multirow{2}{*}{$\begin{array}{c}\text { Step } 3 \\
\text { B }\end{array}$} & \multicolumn{2}{|c|}{ Satisfaction Indices } \\
\hline & & SE & Beta & & SE & Beta & & SE & Beta \\
\hline (Constant) & 1.858 & .421 & & 1.993 & .527 & & 1.107 & .685 & \\
\hline Age & .005 & .005 & .113 & .005 & .005 & .108 & .004 & .005 & .081 \\
\hline Gender & .009 & .069 & .014 & .006 & .070 & .009 & -.015 & .069 & -.024 \\
\hline Household type & .057 & .062 & .090 & .053 & .064 & .084 & .057 & .062 & .090 \\
\hline Education & -.007 & .060 & -.011 & -.013 & .062 & -.020 & .017 & .062 & -.027 \\
\hline Income adequacy & .214 & .058 & $.342 * * *$ & .218 & .059 & $.348 * * *$ & .159 & .061 & $.254^{*}$ \\
\hline Employment status & -.092 & .087 & -.101 & -.096 & .090 & -.106 & -.109 & .088 & -.120 \\
\hline Health status & .024 & .068 & .031 & .022 & .070 & .030 & .060 & .070 & .080 \\
\hline \multicolumn{4}{|l|}{ Year built } & -.001 & .006 & -.012 & -.002 & .006 & -.058 \\
\hline \multicolumn{4}{|l|}{ Number of bedroom } & -.040 & .082 & -.048 & -.026 & .080 & -.032 \\
\hline \multicolumn{4}{|l|}{ Duration } & .000 & .005 & .012 & .001 & .005 & .035 \\
\hline \multicolumn{7}{|c|}{ Satisfaction index of physical environment } & .203 & .295 & .103 \\
\hline \multicolumn{7}{|c|}{ Satisfaction index of social environment } & -.111 & .109 & -.108 \\
\hline \multicolumn{7}{|c|}{ Satisfaction index of resident-controlled environment } & .272 & .165 & .236 \\
\hline
\end{tabular}

Note: $\mathrm{R}^{2}=.169, \mathrm{R}_{\text {adj. }}^{2}=.115, \mathrm{~F}(7,108)=3.140, \mathrm{p}=.005$ for Step $1 ; \mathrm{R}^{2}=.171, \mathrm{R}_{\text {adj. }}^{2} .092, \mathrm{~F}(10,105)=2.166, \mathrm{p}=.025\left(\Delta \mathrm{R}^{2}=.002, \Delta \mathrm{F}(3,105)=.081\right.$, $\Delta \mathrm{p}=.970)$ for Step $2 ; \mathrm{R}^{2}=.245, \mathrm{R}_{\text {adj. }}^{2}=.149, \mathrm{~F}(13,102)=2.544, \mathrm{p}=.005\left(\Delta \mathrm{R}^{2}=.074, \Delta \mathrm{F}(3,102)=3.323, \Delta \mathrm{p}=.023\right)$ for Step 3

$* \mathrm{p}<.05, * * * \mathrm{p}<.001$

Table 16. Summary of Hierarchical Regression Analysis for Variables Predicting Current Residential Environment of Rental Residents

\begin{tabular}{|c|c|c|c|c|c|c|c|c|c|}
\hline \multirow[b]{2}{*}{ Variables } & \multirow{2}{*}{$\begin{array}{c}\text { Step } 1 \\
\text { B }\end{array}$} & \multicolumn{2}{|c|}{ Demographics } & \multirow{2}{*}{$\frac{\text { Step } 2}{\mathrm{~B}}$} & \multicolumn{2}{|c|}{ Housing Characteristics } & \multirow{2}{*}{$\frac{\text { Step } 3}{\mathrm{~B}}$} & \multicolumn{2}{|c|}{ Satisfaction Indices } \\
\hline & & SE & Beta & & SE & Beta & & SE & Beta \\
\hline (Constant) & 2.520 & .347 & & 2.497 & .379 & & -.204 & .693 & \\
\hline Age & .004 & .004 & .148 & .003 & .004 & .126 & .002 & .003 & .060 \\
\hline Gender & .123 & .058 & $.272 *$ & .124 & .062 & $.274 *$ & .124 & .050 & $.273^{*}$ \\
\hline Household type & -.087 & .063 & -.184 & -.069 & .073 & -.148 & -.073 & .058 & -.156 \\
\hline Income adequacy & .039 & .039 & .124 & .043 & .040 & .135 & .014 & .033 & .045 \\
\hline Employment status & .111 & .069 & .214 & .107 & .071 & .205 & .074 & .057 & .143 \\
\hline Health status & -.029 & .046 & -.079 & -.030 & .047 & -.082 & -.029 & .038 & -.079 \\
\hline \multicolumn{4}{|l|}{ Year built } & .002 & .004 & .075 & .002 & .003 & .071 \\
\hline \multicolumn{4}{|l|}{ Number of bedroom } & .021 & .047 & .058 & .007 & .037 & .019 \\
\hline \multicolumn{7}{|c|}{ Satisfaction index of physical environment } & .980 & .280 & $.574 * * *$ \\
\hline \multicolumn{7}{|c|}{ Satisfaction index of social environment } & .089 & .074 & .158 \\
\hline \multicolumn{7}{|c|}{ Satisfaction index of resident-controlled environment } & -.090 & .083 & -.154 \\
\hline
\end{tabular}

Note: $\mathrm{R}^{2}=.149, \mathrm{R}_{\text {adj. }}^{2}=.056, \mathrm{~F}(7,64)=1.606, \mathrm{p}=.150$ for Step $1 ; \mathrm{R}^{2}=.157, \mathrm{R}_{\text {adj. }}^{2}=.019, \mathrm{~F}(10,61)=1.138, \mathrm{p}=.350\left(\Delta \mathrm{R}^{2}=.008, \Delta \mathrm{F}(3,61)=.187, \Delta \mathrm{p}\right.$ $=.905)$ for Step $2 ; \mathrm{R}^{2}=.498, \mathrm{R}_{\text {adj. }}^{2}=.386, \mathrm{~F}(13,58)=4.432, \mathrm{p}=.000\left(\Delta \mathrm{R}^{2}=.341, \Delta \mathrm{F}(3,58)=13.147, \Delta \mathrm{p}=.000\right)$ for Step 3 .

$* \mathrm{p}<.05, * * * \mathrm{p}<.001$ 
For a rental group, the strongest predictor was satisfaction of physical environment $(\mathrm{p}=.001)$, followed by gender $(p=.016)$ and income $(p=.043)$. Rental residents who were female-headed and had college or higher educational background were more likely to positively assess current residential environment if they had satisfaction with physical environment. Also, the regression analysis suggested that satisfaction of physical environment were very a meaningful variable to predict the overall satisfaction of current residential environment among rental residents.

\section{CONCLUSIONS}

As the importance of supportive environment for the elderly has been surfaced, most of the senior housing that has been recently built is the elderly-friendly. In midst of a phenomenon that a sizable number of senior housing designed for independent living has been growing, this research was designed to explore the residential satisfaction of the elderly who had recently moved to two different kinds of senior housing designed for independent living - senior co-op housing and senior rental housing. Using a questionnaire survey by mail, the data were collected in three counties of Twin Cities Area in Minnesota where the substantial number of the elderly and senior housing development had been conspicuous. The satisfaction with current senior living is measured and connotated in three indices of residential supportiveness that are comprised of satisfaction with physical environment, social environment, and resident-controlled management.

Almost all of the responded elderly reported that their senior living as a whole was satisfactory. The statistical finding indicated that satisfaction indices of current senior living significantly and positively contributed to the overall satisfaction with current residential environment. Satisfaction index of physical environment was the only strong factor in predicting the overall satisfaction with current residential environment in senior rental housing, and explained a small proportion of the variance in the dependent variable. The reason is attributed to the fact that the turnover rate of senior rental housing is high due to the privilege that allows the residents who don't like the housing and its features to simply and easily choose to move. Additionally, the rental residents consider as important factors of physical environment for housing choice, in particular affordability and social atmosphere. It's easy for rental residents to move compared to co-op residents due to the nature of each governing structure. In senior co-op housing, residents who want to move out are required to sell the shares they buy when moving in, and the procedure includes the approval of the board that is critical. On the contrary, rental residents give the management office a notice two months earlier than the time they want to move out.

For co-op residents, income adequacy was the only significant factor in assessing their current residential environment. The process of building senior co-op housing is attained and backed by needs of prospective residents, and thus the housing is designed accordingly. The housing is community-based, affordable, and accommodates the elderly who have been living in any given neighborhood for a long time. Because of the special characteristics in the process, none of the factors selected in this study were statistically significant while their satisfaction with the residential environment was positive. Nevertheless, the financing source provided by the public sector is borne to be a financial burden that pays down the principal and its interests causing increases in housing-related cost. In responding to rising cost, income adequacy becomes an important concern since the co-op residents of whom most are house-rich and cash-poor sell their old housing and pay down the housing cost to live in senior co-op housing.

Moreover, the research findings draw an implication that senior housing should be designed to maintain continued lifestyle of older adults, promote utilization of existing resources, and nurture independence without minimizing privacy and autonomy. It is notable that affordability is the biggest concern among residents in senior housing, and it is associated with not just housing-related costs but supportive services. Therefore, senior housing should ensure long-term housing affordability and pursue reduction in service cost by utilizing economies of scale.

As residents in senior housing age their needs evolve, it is necessary to develop long-term planning on service provision and utilization to address changing circumstances resulting from their changing needs. The service should be resident-directed and accessible, and allow residents to have preference for choices.

\section{REFERENCES}

Adams, R.G. (1993). Activity as structure and process: Friendships of older adults. In J. R. Kelly (Ed.), Activity and aging: Staying involved in later life (pp. 73-85). Newbury Park, CA: Sage Publications.

Addae-Dapaah, K. \& Wong, G. K. M. (2001). Housing and the elderly in Singapore: Financial and quality life implications of ageing in place. Journal of Housing and the Built Environment, 16, 153-178

Administration on Aging (2009). A profile of older Americans. Washington, DC: U.S. Department of Health and Human Services.

American Association of Retired Persons (1999). A profile of older Americans 1999. Washington, DC: AARP, Resource Services Group.

Baker, L., Cahalin, L., Gerst, K., \& Burr, J. (2005). Productive activities and subjective well-being among older adults: the influence of number of activities and time commitment. Social Indicators Research, 73(3), 431458.

Bechtel, R.B. (1997). Environment and behavior: An introduction. Thousand Oaks, CA: Sage Publications, Inc.

Citro, J. (1998). Housing characteristics of older households: 1995. Washington, DC: Public Policy Institute, American Association of Retired Persons. 
Clark, F., Azen, S.P., Zemke, R., Jackson, J., Carlson, M., Mandel, D., Hay, J., Josephson, K., Cherry, B., Hessel., C., Palmer, J., \& Lipson, L. (1997). Occupational therapy for independent-living older adults: A Randomized controlled trial. The Journal of the American Medical Association, 278(16), 1321-1327.

Cohen, S. (2004). Social relationships and health. American Psychologist, 59, 676-684.

Conahan, J.M., Silverstein, N.M., \& Fitzerald, K. (2004). Aging in place at Harbor Point: Outreach follow-up of older adults living in independent mixed-income apartments. Boston, MA: Gerontology Institute, University of Massachusetts Boston.

Cooper, M., \& Rodman, M.C. (1994). Accessibility and quality of life in housing cooperatives. Environment and Behavior, 26(1), 49-70.

Elsinga, M. \& Hoekstra, J. (2005). Homeownership and housing satisfaction. Journal of Housing and the Built Environment, 20, 401424.

Frey, B.S. \& Stutzer, A. (2000). Happiness propsers in democracy. Journal of Happiness Studies, 1(1), 79-102.

James, R. N. III (2007). Multifamily housing characteristics and tenant satisfaction. Journal of Performance of Constructed Facilities, 21(6), 472-480.

Kahana, E., Lovegreen, L., Kahana, B. \& Kahana, M. (2003). Person, environment, and person-environment fit as influences on residential satisfaction of elders. Environment and Behaivor, 35(3), 434-453.

Kart, C.S. (1997). The realities of aging: An introduction to gerontology (5th Ed.). Needham Heights, MA: Allyn \& Bacon.

Lee, H. (2003). "Environmental support of independent elderly households in senior co-op housing." Journal of the Korean Housing Association, 14(5), 57-64.

Lee, H. (2004). "Provision of affordable housing for urban seniors in a global era." Architectural Research, $6(2), 1-9$.

Lee, H. (2006). "An analysis of housing policy for the elderly in Singapore." Journal of the Architectural Institute of Korea-Planning, 22(11), 135-142.

Lee, H. (2007a). "An analysis of the housing policy for older adults and senior housing in Hong Kong." Journal of the Architectural Institute of Korea - Planning, 23(4), $37-44$.

Lee, H. (2007b). "An analysis of the housing policy for senior citizens and characteristics of senior housing in Japan." Journal of the Architectural Institute of Korea Planning, 23(12), 11-18.

Lee, H. (2007c). "Residential mobility of the elderly for independent living." Architectural Research, 9(2), 1-9.

Lee, H. (2009). "Housing for middle-class older adults and property management in Hong Kong special administrative region." Journal of the Architectural Institute of Korea-Planning, 25(11), 53-60.

Leibrock, C.A., \& Terry, J.E. (1999). Beautiful universal design: A visual guide. New York: John Wiley \& Sons, Inc.

Lubben, J., Rubinstein, R.L., \& Mintzer, J.E. (1994). Social isolation and social support: an applied perspective. The Journal of Applied Gerontology, 13(1), 58-72.

Metropolitan Area Agency on Aging (2005). A profile of older population in the Twin Cities metropolitan area. St. Paul, MN: Author.

Miller, S.M., Rein, M., \& Levitt, P. (1995). Community action in the United States. In G. Craig, \& M. Mayo (Eds.), Community Empowerment: A reader in participation and development (pp. 112-126). Atlantic Highlands, NJ: Zed Books.

Onyx, J., \& Benton, P. (1995). Empowerment and ageing: Toward honored places for crones and sages. In G. Craig, \& M. Mayo (Eds.), Community Empowerment: A reader in participation and development (pp. 46-58). Atlantic Highlands, NJ: Zed Books.

Prosper, V. (2000). Tenant aging in public and publicly assisted multifamily housing and its public policy implications for housing and long term care. Doctoral dissertation, State University of New York at Albany.

Rohe, W. M., \& Stewart, L.S. (1996). Homeownership and neighborhood stability. Housing Policy Debate, $\underline{7}(1)$, 37-81.

Rossi, P.H., \& Weber, E. (1996). The social benefits of homeownership: Empirical evidence from national surveys. Housing Policy Debate, 7(1), 1-35.

Shaw, B. (2005). Anticiaped support from neighbors and physical functioning during later life. Research on $\mathrm{Ag}$ ing, 27, 503-525.

U.S. Department of Housing and Urban Development. (2000). Housing our elders: A report to Congress. Washington, DC: U.S. Department of Housing and Urban Development.

U.S. Department of Housing and Urban Development \& U.S. Department of Commerce (2008). American housing survey for the United States: 2007. Washington, DC: U.S. Government Printing Office.

Wasylishyn, C., \& Johnson, J.L. (1998). Living in a housing co-operative for low income women: Issues of identity, environment and control. Social Science Medicine, 47(7), 973-981.

(Date of Submission : 2010.1.14) 